\title{
Decentralized Administration and Minority Accommodation in Sri Lanka: Analyzing Status, Issues, Challenges and Prospects
}

\author{
Prof. Dr. Mohammad Agus Yusoff \\ Corresponding Author, Associate Professor, School of History, Politics and Strategic Studies, \\ Faculty of Social Sciences and Humanities, Universiti Kebangsaan Malaysia. UKM Bangi 46300, Selangor, Malaysia \\ Email: agus@ukm.my \\ Mr. Athambawa Sarjoon, M.A \& M.Phil \\ Lecturer, Department of Political Science, University of Peradeniya, Sri Lanka \& PhD Researcher, \\ School of History, Politics and Strategic Studies Universiti Kebangsaan Malaysia \\ Email: sarjoona@gmail.com \\ Dr. Asrinaldi \\ Senior Lecturer, Univasitas Andalas, Pedang, Sumatera Barat, Indonesia \\ Dr. Zawiyah Mohd Zain
}

Senior Lecturer, Universiti Uthara Malaysia, Sintok, Kedah, Malaysia

Doi:10.5901/mjss.2015.v6n4s1p533

\section{Abstract}

One of the major objectives of decentralization is to facilitate the administrative machinery of a government to deliver public services efficiently and effectively to all segment of public, including the minority groups living within a state. In a multi-ethnic country, the decentralized administration with specific provisions and institutional arrangements can help to promote and protect the rights and privileges of minorities. However, in Sri Lanka, decentralization has been a contested topic of debate in terms of minority accommodation. This study attempts to access the constitutional and institutional arrangement of ethnic minority accommodation in decentralized administration, the status of their practice, and the related issues in Sri Lanka. The finding reveals that even though Sri Lanka has adopted decentralized administrative system at different levels, but it has failed to accommodate the rights and interests of ethno-linguistic minorities within the system. The study identifies the nonimplementation of the constitutional provisions on minority language (Tamil) in administrative affairs as one of the key factors motivated to the minority grievances in decentralized administration in Sri Lanka. It is further identified that the lack of commitment to follow and implement the constitutional provisions and the acts of ethnic discrimination and marginalization in administrative affairs have compelled the minorities to claim and advocate for more institutional and policy reforms in decentralization discourse in Sri Lanka.

Keywords: Decentralization, administration, minority accommodation, and Sri Lanka.

\section{Introduction}

From 1950s onwards, decentralization has become one of the most popular subjects in the fields of administration and local governance and has been popularized with different thematic emphasis such as, political independence, regional and local development, good governance, service delivery, conflict management, ethnic accommodation and so on. It has been a trend that decentralizes powers and works of central government institutions to the regionally or locally functioning institutions in order to improve better service delivery; to facilitate regional or divisional development; and to empower the regions and regionally concentrated groups of people. In the recent past, decentralization has been considered as one of the mechanisms to accommodate minority groups, by strengthening them through decentralized power, institutions and budgetary allocation, especially concerning to serve, develop and empower them and their areas. Decentralization of power has three dimensions, namely, political, administrative and fiscal. Decentralization of political powers empowers the minority groups in term of ethnicity, language, region etc. in the process of decision-making and giving them equal 
status or recognition which allow them to select or elect their political representatives at local level. On the other hand, both fiscal and administrative decentralization allows local public to decide the tier development needs, revenue incomes and allocate money, monitor the progress and facilitate service delivery and to protect and promote the distinctive features of groups' identity.

Governments in many countries consider one or many aspects and outcomes of decentralization when efforts taken for decentralization initiatives as part of state reform in order to accommodate the rights and interests of diverse ethnic groups. There are number of countries successfully implementing number of reforms focusing on the minority accommodative perspective of decentralization both in political governance and administration. Some have failed due to a number of factors, especially to the lack of commitment in planning and implementing those reforms and policies. In Sri Lanka too, number of decentralization policy reforms have been introduced focusing on the accommodation of minority interests and rights. But the ethno-linguistic minorities are still demanding and requesting the government to reform the state machinery through decentralization policies towards empowering them, and to properly implement the existing arrangements. Number of studies has also identified that most of the past decentralization initiatives have failed to accommodate many aspects of the rights and interests of ethno-linguistic minorities in Sri Lanka. The main objective of this research is to assess the nature of existing decentralized system of administration and their extent of accommodating or marginalizing the rights and interests of ethno-linguistic minorities at provincial, district and divisional levels of administration. There are different kinds of administrative issues; however, the major thematic focus of this research is to analyze the linguistic problems facing by the Tamil-speaking minorities within the decentralized administrative machinery. The rest of the article is divided into three major parts with the conclusion. The next part gives a brief conceptual note on decentralization as a tool to accommodate rights and interests of minorities followed by the review of the historical development of decentralized administrative machinery in Sri Lanka. The next part examines the linguistic and other issues and concerns of minorities in decentralized administration in Sri Lanka followed by concluding remarks. This research has incorporated only the secondary date collected from different sources. The analysis is descriptive and interpretive in nature.

\section{Decentralization as a Tool to Accommodate Rights, Interests And needs of Minorities: A Conceptual Note}

\subsection{Introduction}

There are bulks of literatures based on theoretical and empirical analysis on different perspectives of decentralization. However, most of them are on political perspectives and few are on administrative and fiscal perspectives. Those few studies that exist on administrative decentralization have either focused entirely on the administrative efficiency of political and administrative units or their capacity to run or manage development projects at local level. These researches have paid little attention on the minority accommodative perspectives of administrative decentralization. Administrative decentralization also has a conflict reduction and ethnic cohesion rule in plural societies, by allowing minority groups to participate in administrative affairs of not only development process but also in every aspect of political and administrative units at local level. In this set-up, minorities also are empowered and equally treated in local administration and policy oriented development.

On the other hand, literatures on ethnic politics have also not touched deep upon decentralization, or even on public administration. Those literatures assume that public administration is merely instrumental to political decisions. But, as Esman (1997) indicates, in most of the developing countries, ethnic and other minorities are mobilized to defend their collective rights and interests in order to protect and promote their identity, status, economic opportunities, and political power, in competition, with other ethnic communities (mostly with majorities) in opposition to government policies and projects due to their failure to address or accommodate the rights and interests of the minority groups. In most cases, they favored the interests of majorities. In many ethnically plural societies, conflicts emerge mostly by advocating decentralization of power from center to periphery, or regions, or local level due to the lack of balance of power between the ethnic majorities and the ethnic minorities. Therefore, politicians, administrators, international actors and mediators identify and advocate decentralization as a tool to accommodate ethno-linguistic, religious or regional minorities and to mitigate or resolve conflicts emerge among groups.

\subsection{Defining decentralization and its dimensions and forms}

As a concept, decentralization, its dimensions and forms are more complex to define. Basically, scholars find decentralization as involves in transfer and delegation of authority and responsibility from a higher level of government 
authorities to the lower level for making decisions in number of local affairs in the processes of development planning and implementing, in order to boost rural and regional development, improve service delivery, empower and accommodate local groups in local politics. In their writings Cheema \& Rondinelli, scholars on decentralization studies simply define decentralization as the transfer of authority, responsibility, and resources through de-concentration, delegation, or devolution from the center to lower level of administration (Rondinelli \& Cheema 1983; Cheema \& Rondinelli 2007). According to their definition, through decentralization, the power and authority be vested by central government bodies in the process of public policy-making are transferred or delegated to the local level governance and administrative bodies. Conyers defines decentralization as "a process of change in which functions previously undertaken by government institutions at national level become the responsibility of government or non-government institutions at subnational level" (Conyers 1999:2). According to her, decentralization is a process which involves a transfer of functions from national to subnational levels. Based on the above definitions, decentralization can be summarized as a process of transfer or share or re-distribute powers and authorities, wasted by the institutions and officers of central government to regional and local level of government institutions and officers.

Decentralization may take many different types and forms and there is a close relationship between the objectives of decentralization and the form which it takes. There are three more fundamental types of decentralization namely political, fiscal and administrative decentralization. Political decentralization refers the alteration to the structure of government through the devolution of power and authority to the lower level government institutions. It reflects whether sub-national governments are directly elected, and thus share in the political functions of governance (Faust \& Harbers 2011). Political decentralization also increases the participation of citizens and civil society in their selection of governmental representatives and in political decision-making. Fiscal decentralization entails the transfer of powers to local level government institutions to raise and retain financial resources to fulfill assigned responsibilities (Cabral 2011). This kind of decentralization forces the localities to rely less on financial transfers from the central or provincial governments and more on extra budgetary and own generated funds to fill the gaps in local budgets. Administrative decentralization, on the other hand, involves in the full or partial transfer of any array of functional responsibilities to the local level public institutions. According to Ayenew (1998), administrative decentralization involves the sharing of responsibility and authority between headquarters and the field offices. The functions and authority are delegated as a matter of administrative expediency and can be revoked by the center when circumstances warrant. Existing literatures have categorized administrative decentralization generally using three terms, most commonly labeled as deconcentration, delegation, and devolution. De-concentration involves a bureaucratic and hierarchical relationship; delegation involves a contractual relationship; and devolution involves an arm's-length relationship (Scheneider 2003).

\subsection{Minority accommodative motive of decentralization}

Conceptually, decentralization helps to achieve a number of different objectives. One of those objectives is to accommodate rights and interests of minorities through policies and institutional restructuring within the larger political and administrative systems. Many argue that decentralization can be used to ease tensions among ethnic groups in postwar as well as post-conflict societies. By devolving authority and responsibility to local level political and administrative units, the central government may seem less threatening, and all groups including minorities can run their own affairs and settle their grievances with their own mechanism or without the interference of central government (Brinkerhoff 2005; Grasa \& Comps 2009; Siegle \& O'Mahony 2009; \& Gjoni \& Dunbar 2010).

Decentralized powers aimed to accommodate rights, interests and needs of various distinct and separate cultural, religious, ethnic, or linguistic groups. The high degree of autonomy offered through decentralization process to minorities may actually mark a turning point in the process of resolving ethnic conflicts and enhancing national cohesion (Gjoni \& Dunbar 2010). The conflict-mitigating rational of decentralization in ethnically diverse societies will ensure minority group's participation and representation at local and national levels. It provides political channels, through which differences can be reconciled. In this way, decentralization is seen as a flexible institutional mechanism to accommodate the varied priorities of diverse populations within a state. The greater level of minority participation and their voice in public sphere expected under decentralized system are also seen as stabilizing force for democracy and good governance. Besides, decentralization supports to reduce ethnic conflict and secessionism by bringing government closer to the people, increasing opportunities to participate in government activities, and ultimately giving groups control over their local political, social and economic affairs. As Brancati (2006:655-656) indicates, decentralization prevent conflicting groups from fighting each other over what they perceive as unfair treatment by another group. According to Cheema and Rondinelli (2007), transforming power and authority from central government to sub-national administrative and local government units and opening the political process to widespread participation provide an institutional framework for local 
autonomy and empower local communities to pursue local aspirations. Similarly, as Siegle \& O'Mahony (2009), indicates, if citizens believe government is concerned and responsive to their needs, then citizens have recourse to reconcile their grievances. Therefore, as Lake \& Rothchild (2005) claim, if properly designed, decentralization would be an institutional machinery that can potentially benefit both political minorities, who can be induced or compensated not to secede from the state, and political majorities, who gain countrywide acceptance of state institutions.

The success of decentralization would be challenged by lack of trust and reciprocity in post-conflict environments. However, in many countries in transition from conflict to post-conflict development and peace-building, forms of decentralization appear to be the helpful devices, bringing the state closer to the people and allowing ownership among different groups, including minorities. Decentralization initiatives allow people to express their needs more effectively and enable authorities to develop autonomy and deliver public services more efficiently. In smaller decentralized units, the chance of efficient governance and of sanctioning corruption seems to be higher (Linder 2009).

The process of accommodation and empowerment of minorities in many post-war and post-communist countries has coincided with decentralization of many unitary democratic governments such as Great Britain, Sweden, or France in Europe. It was understood by many European policy makers and experts that decentralization of decision-making power with appropriate systems and instruments is generally seen as an important way of improving the performance of the civil service (Flynn \& Strehl 1996). On the other hand, for most developing countries in Latin America, decentralization has been often viewed as part of the deepening process of democratization. Countries such as Bolivia and Ecuador have linked decentralization to a quite radical political and institutional transformation project, aimed at empowering local actors and reducing structural and territorial inequalities. Still others have preceded decentralization more smoothly to strengthen local governments (for example, Paraguay), regional bodies (for example, Peru) and existing federal systems (for example, Brazil and Argentina). In the case of most Asian countries, decentralization has been adopted in order to empower different groups of people and to improve public services to the larger populations, including minorities. But, the degree and the forms of decentralization in terms of granting autonomy and assigning duties to the local institutions greatly vary among developing countries. Some countries have a strong tendency and a long history of centralization. On the other hand, most big countries like Argentina, Brazil, China, and India have also used decentralization positively to cater the needs of the larger local population.

\section{Decentralized Administrative Machinery in Sri Lanka: Historical Development}

Like many democratic countries, Sri Lanka too has adopted a kind of decentralized administrative system. The modern system of decentralized administration is the provincial administration which was officially introduced by the British rulers in 1833. However, the British started to administer Sri Lankan territory through a kind of provincial administration from 1796. The appointment of a Resident and Superintendent of Revenue with the three collectorship under him, one for Jaffna and Mannar, one for Colombo and Galle and the other for Trincomalee and Batticaloa between 1796 and 1798, marked the beginning of the provincial system of administration in Sri Lanka (Tressie Leitan 1979). Later, the British sponsored Calebrooke-Cameron Commission recommended changes in 1833 which had far-reaching affects not only on political but also on administrative machineries of the country. In order to strengthen the British colonial policy of that time, in 1833 a uniformed administrative system was adopted, and then the entire country was divided into five provinces, each under a Government Agent (GA) with provinces sub-divided into districts each under an Assistant Government Agent (AGA). Though the position of GA is treated as a top of the British colonial administration, a similar position known as the 'Disave' with more or less similar powers could be found in the local administration in the traditional Kandyan Kingdom which lasted from $16^{\text {th }}$ century to the second decade of the 19th century (Ranasinge 2014).

The primary function of the colonial GA was to collect revenue, administer law and order, allocate 'Grown' land, and supervise irrigation (Devendra 2010). However, the GA's powers were wide and varied as he was the head of every government department, and was endowed with magisterial authority to preside over judicial proceedings and punish the guilty (Devendra 2010). Below districts, divisional and village level were manned by locally appointed officials called as Divisional Revenue Officer (DRO) and Village Headman (VH) respectively (Nadarajah 1997). DROs were selected by a competitive examination, first held in 1939, and given a pretty through training. Interestingly, the DRO service was divided according into ethno-linguistic group - Sinhalese, Tamils and Muslims - and were accordingly, assigned to administer their respective 'traditional homelands' (Devendra 2010). DRO divisions were composed of villages grouped into Village Headman's divisions under a Village Head who was selected by the GA from a prominent local family on the recommendation of DROs.

The above system of decentralized bureaucratic administration existed almost unbroken for about 100 years, up to Donoughmore reform in 1931, but the number of provinces and districts was only undergoing alteration. The 
Donoughmore reforms introduced the dimensional changes in both governance and public administration. With the introduction of number of political initiative, for example, introduction of universal franchise, executive group system, board of ministers, the reforms resulted in transfer of functions away from the GA. For now, elected ministers were made responsible (individually) for the functioning of departments which were placed under them. Between 1931 and 1946, there was thus a movement away from the GA. The period 1948 to 1989 was comparatively a stable one as far as the organization of the administration concerned. In 1955, the district replaced the province as the country's main administrative unit. By 1956, there were 20 administrative districts and each were designated the GAs (Devendra 2010). The GAs were vested with the tremendous authority as the representatives of the government in the districts. Their original responsibilities for maintaining law and order, and justice gradually came to be handled by the police and judiciary. However, the GAs yet retained residuary control over police which was exercised only during major civil disturbances. During this period, a number of efforts were made to strengthen not only the civil service but also the development administration of the country.

Since 1970s, in an attempt to address critical problems such as unemployment and high poverty levels, Sri Lanka has experienced much public sector reforms. Many of the reforms revolved around decentralization (Samaratunge \& Bennigton 2002). With the introduction of District Political Authority (DPA) system in 1974, the district administrative machinery gained political direction, by a designated District Minister to the GA's activities. Initially, the DPA was designed mainly to organize rapid concerted action in each district and thereby expedite the food production program which was receiving the highest priority of the government at that time (Tressie Leitan 1979). In each district, therefore, a senior member of the National State Assembly - sometimes a deputy or cabinet minister - was appointed by the Prime Minister as Political Authority and assigned special responsibilities with 'decentralized budget allocation.' It was hoped that the system would be a remedy for the prevailing serious imbalance between the development of political intuitions and the bureaucracy in Sri Lanka (See: Wijeweera 1988). However, this devise had a short life and met sudden death when the United National Front (UNF) government was defeated at the 1977 parliament election which transferred power to the United National Party (UNP). The UNP government introduced the District Development Councils (DDCs) system through the District Development Councils Act No.35 of 1980 with responsibility for district level planning and plan implementation. The DDC was chaired by a District Minister. The political coordination and guidance for the decentralized administration were provided by the President's Office and the cabinet while administrative coordination, guidance and control at the center were in-charged with the ministry of Finance and Planning, Plan Implementation, Public Administration and Home Affairs (Karunanayake \& Abhayaratne 2002). However, the DDCs failed to perform the expected roles in preparing development plans for districts. Studies have identified that even though the DDC concept represented a significant innovation as it provided horizontal coordination at the grassroots level; however, policy implementation was poor and created a series of management problems. Studies further found that there were problems of poor management, poor project choice, restrictive controls, and a lack of commitment. The whole structure of the DDC was too weak to deliver services to the citizenry in rural areas and there was no consistency between the interests of the local elite and the objectives of decentralization (See: Matthews 1982; Oberst 1986 \& Samaratunge \& Bennigton 2002). On the other hand, DDC system had nothing given any priority concern in accommodating ethno-linguistic minorities by establishing special DDCs in areas they live predominantly.

A clear shift in policy relating to sub-national level of administration and planning was evident during the late 1980s. This was marked with the $13^{\text {th }}$ Amendment to the constitution adopted in 1987 which paved the way for the Provincial Councils Act No. 42 of 1987. This Act enabled the devolution of political and financial powers to a system of Provincial Councils (Tressie Leitan 1997). The main theme of the introduction of this Provincial Council (PC) system was to create more responsive methods of public service delivery, but it failed to achieve its objectives for a number of reasons. First, there was lack of coordination between different levels of government. Second, there was an imbalance between the political institutions and the bureaucracy that allowed bureaucrats to formulate and implement public policies without appropriate political guidance, which made the situation more complex. Third, a high degree of political influence was one of the main obstacles to the smooth functioning of public sector reforms (Gunawardena et al 1994; also see: Amarasinghe 2010; Bandara 2010 \& Sivakumar 2013).

At present under decentralized administration, there are 9 provinces, 25 districts, 332 divisional secretariats divisions in Sri Lanka. Further, in order to ensure an administrative system at rural level, 14054 Grama Niladhari (GN) divisions have also created under 332 Divisional Secretary's (DS) divisions. At the time of independence, there were only 20 districts and Moneragala district was created in 1959 followed by Amparai in 1961. Both Mullaitivu and Gampaha districts were created in 1978. Kilinochchi was the last district created in 1984, and the current constitution (that of 1978) states that the territory of Sri Lanka consists of 25 administrative districts which may be subdivided or amalgamated by a resolution of the Parliament of Sri Lanka (Parliament Secretariat 2011; Aponso 2013). Each province is administratively 
headed by a Governor who is appointed by the President along with the set of higher administrative officers. The Governor is the administrative and executive head of the provincial councils; however, there will be a body of elected members who will exercise the decentralized powers within the provincial limits. Each district is administered under a District Secretary who is also appointed by the President. The District Secretariat is the chief administrative body of a district and serves as the central government's gate for coordinating its administrative functions at the district level. They also take major role in aggregating district level development planning and budgeting. The main tasks of a District Secretariat involve coordinating communications and activities of the central government and Divisional Secretariats.

In order to facilitate the district administration, each district is divided into administrative sub-units known as Divisional Secretariat (DS), headed by Divisional Secretary. The Transfer of Powers (Divisional Secretaries) Act No 58 of 1992 introduced the DS system altering the old AGA system. The DS divisions have planning, coordinative as well as implementation functions within their jurisdictions. They carry the overall responsibility of delivering public services at local level. Programs and action plans are prepared at the central level by the line ministries of the central government, and implemented by the respective officers at the DS divisions. Officers deployed to DSs are hired by the line ministries to which they report back through the district secretariats (Jinapala et al 2012). At present, DSs have been granted more powers and responsibilities in terms of service delivery at the divisional level in comparison to the District Secretariats.

\section{Linguistic and Other Issues and Minority Concerns in Decentralized Administration}

In Sri Lanka, the matter of decentralization of power to sub-national governance machinery has been the subject of debate and experimentation since independence. As Samratunge \& Bennigton (2002) indicates, influenced by the British, the political and administrative structure of Sri Lanka is highly centralized and more focused on process rather than outcome. However, as Tressie Leitan (1990) has rightly mentions, in Sri Lanka, decentralization of political and administrative power was discussed not only as a response to the demands of ethnic minorities, but also in recognition of the need for participatory development and as a reaction against highly centralized colonial bureaucratic structures. But, most of the initiatives have failed to achieve their expected targets. Many political and administrative institutions have been formed at provincial, district and divisional levels through number of constitutional provisions and policy development in order to accommodate the rights and interests of ethno-linguistic minorities, but, still minorities are facing number of issues and challenges with regards to the decentralized administration in Sri Lanka. Minority ethnic groups have been demanding and advocating for the fully implementation of minority rights provisions adopted in the constitution pertaining to public administration and, to restructure institutional set-ups at provincial, district and divisional levels in order to accommodate the segment of ethnic minorities living within majority groups, and to deliver and access the public service easily and affectively. One of the major issues concerning the rights accommodation of minorities is the language issues in administration. The following section reviews the historical development of language politics, politics of recognizing minority (Tamil) language and the issues in implementing Tamil language provisions in administrative affairs.

Historically, both the Sinhala and the Tamil languages have been the major languages of the native people of Sri Lanka. But, the colonial rulers, especially the British made English as official language during their regime. No conflict of interests emerged in terms of language among Sri Lankans up to independence. But, when SWRD Bandaranyake introduced Sinhala as the only official language replacing the English in 1956, it caused number of difficulties to the Tamil-speakers and it induced them to advocate for the recognition of Tamil as official language equal to Sinhala. In between 1956 - 1958, there were number of agitations for and against Tamil language movement which led to the introduction of Tamil Language (Special Provisions) Act No.28 of 1958. The Act clearly stated that in the northern and the eastern provinces the Tamil language may be used for prescribed administrative purposes (Perera 2008:9; DeVotta 2004:211-212). Therefore, this Act was viewed as an attempt to accommodate the Tamil-speaking ethnic minorities within the system of decentralized administrative machinery.

However, the above Act was not fully implemented in the administration of north-eastern region. But, government continued to administer the Tamil-speakers majority districts in the north-eastern provinces in Sinhala and most of the communication from central government to district and divisional levels of administration were continued to be sent in Sinhala language violating the Tamil Language (Special Provision) Act of 1958. The Tamil-speaking public officers were compelled to gain competence in Sinhala language in order to sustain in public service. In fact, this caused the resignation of a considerable amount of Tamil-speakers from the public service in the early period of the implementation of the Sinhala Only Act.

A good example of the extent of the violation of Tamil Language Special Provision Act can be found in the district administration of Amparai. Amparai administrative district was formed in April 1961. As a district in the eastern province with the absolute majority of Tamil-speakers in its population, the district got legal recognition to be administered in Tamil 
language, according to the 1958 Tamil Language Act. But, without considering ground realities and the Tamil Language (Special Provision) Act of 1958, government appointed a Sinhalese GA and established the district secretariat in Sinhalese majority area. All these automatically led to the domination of Sinhalese and Sinhala language in a Tamilspeakers majority district which caused them number of difficulties in fulfilling services at district secretariats. Further, government continued to appoint Sinhalese to the top of the district bureaucracy sidetracking the claims of the minorities. In fact, studies reveal that the domination of Sinhalese and their language in district administration of Amparai has immensely pushed the Tamil-speakers of district to claim and advocate for a separate administrative district covering the areas they live (See: Ibrahim 2001 \& Jabbar 2013).

As a response to the agitations made by the Tamil-speakers with regard to recognize Tamil as an official language, the government adopted two constitutional amendments (13 ${ }^{\text {th }}$ and $\left.16^{\text {th }}\right)$ in 1987 and in 1988, respectively. Accordingly, the revised articles 22 (1) of the Constitution states that Sinhala and Tamil shall be the languages of administration throughout Sri Lanka and Sinhala shall be the language of administration and be used for the maintenance of public records and the transaction of all business by public institutions of all the provinces of Sri Lanka other than the northern and the eastern provinces where Tamil shall be so used. Section 25 of the Chapter IV further states that the state shall provide adequate facilities for the use of the languages provided for in this Chapter (Parliament Secretariat 2011:10). The above two legislative amendments on Tamil language rights were supplemented by the Official Languages Commission Act (No. 18) of 1991, as well as government directives through gazette notifications and Public Administration Circulars. The objectives of the setting up of Official Language Commission (OLC) were to recommend principles of policy, relating to the use of the official languages; and to monitor and supervise compliances with the provisions contained in chapter IV of the constitution; promote the appreciation of the official languages and the acceptance, maintenance, and continuance of their status, equality and right of use (Shanthakumar 2010). However, according to many studies, no meaningful results were produced by the OLC on the matter of admitting Tamil language in public affairs due to number of shortcoming of the commissions (See: DeVotta 2004; Perera 2008 \& Santhakumar 2010).

In the case of north-eastern and central provinces, Tamil-speaking ethnic minorities — the Tamils, the Muslims and the Indian Tamils - have continued to be suffered greatly due to the violation of Tamil language provisions and the domination of Sinhala language in administrative affairs. The northern and the eastern provinces have predominantly Tamil-speaking population, but, both provinces have been continued to administer by Sinhalese governors. As governor is expected to be represented the President at the province, in some provinces governor may act against the interests of the elected members of the provincial council who exercise the real political power. This was the case in the provincial administration in northern and the eastern provinces where minority ethnic groups live predominantly. From their inception, for most of the period, these provinces have been governed by Sinhalese governors who have pure knowledge in Tamil language and have been exercising excess powers on behalf of country's president in the provincial affairs, despite many demands and request posed by the Tamil-speaking people to appoint a governor from Tamil-speaking community. Under the administration of Sinhalese Governors and his officials appointed by the President who always responsible to the President, Tamil-speakers in these provinces became to face number of grievances in terms of Sinhala domination, rigid control of Governor, and other kind of issues in daily affairs of provincial administration. This has caused not only to violate the legitimate rights of Tamil-speakers but also to control them from exercising the provincial level autonomy guaranteed in the constitution.

The linguistic issue in district administration has been a remarkable issue facing by the minorities (especially in the north-eastern part) in Sri Lanka. Out of eight districts in the north-eastern province, the administrative heads in four districts are Sinhalese, at present (in 2015). The appointment of Sinhalese administrative elites in the Tamil-speakers' majority districts of Amparai and Trincomalee ultimately led not only to violate the constitutional provisions on administering these districts in Tamil language but also to easily implement the ethnic oriented policies and development projects designed by the central governments in these districts through district administrative machinery. Using the authority of issuing Grown Land, these GAs were instrumental for marginalizing minorities in irrigation based development initiatives and allocating more state lands for the landless Sinhalese. The project of Gal Oya in Amparai district and Alle, Kantalai and Morawewa in Trincomalee district were some among many cases in this regard. In general, the present institutional structure of district and divisional administrative machinery has also not only isolate decisionmakers from citizens but also marginalize the involvement or participation of local public in district and local level policyplanning and policy-implementation process.

The case of district and divisional level administration in Nuwara Eliya district is another example in terms of minority grievances in decentralized administration in Sri Lanka. The district has 60 percent population of Tamil-speakers, mostly Indian Tamils, but the district secretariat is fully controlled by the Sinhalese administrators. In this district, out of the five DS divisions, Indian Tamils are living predominately in two DS divisions, but both are fully controlled by the 
Sinhalese administrators and conducted in Sinhala language. There has been more demands and voices among this community to delimit the boundaries of the DS divisions and to form more divisional and GN divisions to cater the needs of the people, and to conduct the administration in Tamil language, however, no meaningful initiative has taken up to now. It is worth noting here that there are DS divisions created with less than 10,000 populations for the interests of other ethnic groups, but in Nuwara Eliya district, only 5 DS divisions have been formed for a population of 711,644 and most importantly, one particular DS office has a population of 205,723 and among them 147,300 are Indian Tamils, but are fully controlled by the Sinhalese administrators (Department of Census and Statistics 2014). This is really a strange setup in terms of decentralized administration to the people of Indian Tamils experiencing more difficulties in getting public services at district and divisional offices of administration.

In the post-war context too, the recognition of Tamil language and the implication of Tamil language provisions have been severely threatened and neglected by the Sinhalese nationalist forces and the administrators. The case of ban on singing national anthem in Tamil language has been a contested issue in terms of recognizing and respecting cultural features of minorities in administrative affairs. After independence, the national anthem was written in the language spoken by the majority of its inhabitants. Subsequently, it was translated into Tamil language widely spoken by three major ethnic minorities. While the song in the language of the majority received pride of the place, provisions was made for both versions of the anthem to be sung whenever or wherever necessary. This provision had been maintained in administrative affairs too until up to the issues raised by the nationalist forces after 2009. Immediately after the end of civil war militarily, the nationalist forces took this matter a serious issue and convinced the rulers to ban the provision to sing the national anthem in Tamil. This was the serious topic of debate in 2010 and ultimately government officially banned that provision and ordered the administrators to sing the anthem only in Sinhala language. Since, national anthem and national flag are the elements of expression of national unity of citizens of a country; this ban was viewed by the Tamilspeakers as violation of their fundamental rights and received huge criticisms from them. Even through the new president has lifted the ban in April 2015, but still there are challenges and threats to sing the anthem in Tamil language.

On the other hand, the Sinhalese administrators appointed after civil war in the predominantly Tamil-speakers living districts of Mannar, Vavuniy, Trincomalee and Amparai in the north-eastern region have been instrumental in sinhalization of administration violating the Tamil language provisions. They are always non-supportive to the implementation of Tamil language provisions even on the context of high pressure comes from public and government authorities. There are many demands prevail among minority communities and the pressures come from many sources to re-organize the administrative structures in the war-affected north-eastern region in order to facilitate the Tamil-speaking minorities; however, the reform process is not up to the level of satisfaction.

It is noteworthy here that even though Sri Lanka is a developing county, no any major change happened with regard to institutional set-up of district administration over the last fifty years, and no new administrative district is formed in the past thirty years period as a mechanism to facilitate ethno-linguistic minorities in administration; to boost development initiatives, and to strengthen service delivery at local level. On the other hand, there have been demands, especially among minorities for the creation of new district and DS divisions not only to facilitate the local administration but also to conduct administration in their own language. But, no meaningful initiatives have taken by the respective authorities on this regard.

\section{Conclusion}

Historically, Sri Lanka had been ruled through its own inherited system of decentralized administration. In this system, for the administrative easiness, the whole country or kingdoms was subdivided into local units and each local units enjoyed a considerable level of decentralized power and autonomy. In some part of the country, local administrative units were formed to cater the needs of the local people, especially of ethnic minorities, and those units were headed or represented by the leaders or the representative of the same groups. The colonial rulers, especially the British who introduced modern system of decentralized administration also provided mechanism in order to cater the interests and needs of the diverse people, especially of ethnic minorities in their system of governance and administration. But, post-independence onwards, Sri Lanka's decentralized administration has come to suffer greatly due to its incapacity in accommodating the ethnic and linguistic minorities within the system. As identified above, in the process of state formation in postindependence Sri Lanka, number of mechanisms to accommodate the rights, interests and needs of minorities were adopted through constitutional and legal reforms and institutional restructuring. However, the domination of ethnic majority - Sinhalese - and their language - Sinhala - in many ways, has come to challenge the inclusion of ethnolinguistic minorities within the decentralized administrative system. In many levels of administration, the Tamil-speaking minorities have been facing number of issues and challenges in terms of linguistic barriers and majority domination. Non- 
implementation of constitutional and policy provisions on admitting Tamil language, and the lack of commitment among ethnic majority to facilitate Tamil-speakers within the administrative machinery have been identified as the major factors to the issues facing by the ethnic minorities in decentralized administration. It is worth noting at this juncture that the proper implementation of any act, circular or directive will be meaningful only under the proper institutional set-up and its rational functioning. Failure of strengthening the implementing agencies or institution with sufficient personnel and other facilities would definitely challenge the objectives and outcomes of any initiative.

In pluralist societies, public administration needs more policy reforms and institutional modernity in order not only to adopt the new trends in public and development administration but also to accommodate the rights and interests of the different groups of people, especially of minorities at different level of administration. Conceptually, decentralization of power and authority is one of the best ways not only to improve service delivery, boost regional and local development, strengthen local sustainability and enhance the participation of local people in decision-making and prioritizing their local development, but also decentralization helps to empower and enhance the rights and status of minorities and marginalized people, if carefully designed and implemented. In Sri Lankan context, as viewed above, even though there is a system of decentralized administration, but for the last 30 years, no major policy reform and institutional restructuring have been made to the system with the purviews of strengthening development administration and minority accommodation. Modernizing and restructuring administrative machinery through decentralization concept has been considered by many developing countries as a mechanism for further development. As a developing country with pluralistic in nature, Sri Lanka needs more policy reforms and restructuring of existing institutional set up for establishing equity and inclusive sustainable development with lasting peace.

\section{References}

Adamolekum, L. (1991). Decentralization policies: Problems and prospects. Asian Journal of Public Administration, 13(1), 67-92.

Ahikire, J. (2002). Decentralisation in Uganda today: institutions and possible outcomes in the Context of Human Rights. Geneva: International Council on Human Rights Policy.

Amarasinghe, Y.R. (2010). Introduction. In Amarasinghe, Y.R, etal. (Eds). Twenty two years of devolution: an evaluation of the working of provincial councils in Sri Lanka. (pp.1-14). Rajagiriya (Colombo): Institute for Constitutional Studies.

Aponso, H.A. (2013). Provinces and districts of Sri Lanka: past, present and future. Daily Mirror [Online] Available: http://www.daily mirror.Ik/opinion/172-opinion/36732-provinces-and-districts-of-sri-lanka-past-present-future.html\#sthash.srRMVM5X.dpuf (November 16, 2014).

Ayenew, M. (1998). Some preliminary observations on institutional and administrative gaps in Ethiopia's decentralization processes. Addis Ababa: Addis Ababa University.

Bandara, A.M. (2010). Provincial public administration. In Marasinghe. L., \& Wickramaratne, J. (Eds). $13^{\text {th }}$ Amendment essays on practice. (pp.164-189). Pannipitiya, Sri Lanka: Stamford Lake Publication.

Brancati, D. (2006). Decentralization: Fueling the fire or dampening the flames of ethnic conflict and secessionism?. International Organization, 60, 651-685.

Brinkerhoff, D. W. (2005). Rebuilding governance in failed states and post-conflict societies: Core concepts and cross-cutting themes. Public Administration and Development, 25(1), 3-14.

Cabral, L. (2011). Decentralisation in Africa: scope, motivations and impact on service delivery and poverty. Brington: The Future Agricultures Consortium, University of Sussex.

Cheema, G. S., \& Rondinelli, D. A. (2007). From government decentralization to decentralized governance. In G.S.Cheema \& D.A.Rondinelli (Eds). Decentralizing governance: emerging concepts and practices. (pp.1-20). Washington D.C: Brooking Institute Press.

Conyers, D. (1999). Decentralization: A conceptual analysis. Paper presented at Ministers' Conference on Local Government in Eastern and Southern Africa, Victoria Falls, Zimbabwe. 21-23 September 1999.

Devendra, T. (2010). Memories of a pen pusher: Kachcheries and commissions. Colombo: Vijita Yappa Publishers.

DeVotta, N. (2004). Blowback: linguistic nationalism, international decay, and ethnic conflict in Sri Lanka. Stanford, CA: Stanford University Press.

Drick, B.W., \& Omar, A. (2006). Decentralization and community empowerment: does community empowerment deepen democracy and improve service delivery?. Washington: Office of Democracy \& Governance, USAID.

Duncan, C. (2007). Mixed outcomes: The impact of regional autonomy and decentralization on indigenous ethnic minorities in Indonesia. Development and Change, 38(4), 711-733.

Esman, M. J. (1997). Public administration, ethnic conflict, and economic development. Public Administration Review, 57(6), 527-533.

Faust, J., \& Harbers, I. (2011). On the local politics of administrative decentralization: Applying for policy responsibilities in Ecuador. Publius: The Journal of Federalism, 42(1), 52-77.

Flynn, N \& Strehl, F. (1996). Public sector management in Europe. London: Prentice Hall.

Gjoni, R., Wetterberg, A., \& Dunbar, D. (2010). Decentralization as a conflict transformation tool: The challenge in Kosovo. Public Administration and Development, 30, 291-312. 
Grasa, R., \& Camps. A. (2009). Conflict prevention and decentralized governance: Some remarks about the state of the art in theory and practice. Barcelona: International Catalan Institute for Peace.

Gunawardena, A.S.S, Gunawardena, Y.W, Nanayakkara, G \& Pathmanathan, N. (1996). Provincial Councils: operational experience of devolution. Colombo: Ministry of Co-operative, Provincial Councils, Local Government and Indigenous Medicine.

Ibrahim, I.L.M. 2001. Coastal administrative district. Sammanthurai: Author's Publication.

Jabbar, M.A. 2013. Creation of new administrative district for Tamil Speaking people in Amparai. A critical analysis. Kalam: Faculty Journal of Arts and Culture, 7, 80-92

Jinapala, K, Somaratne, P.G, Ariyaratne, B.R \& Merrey, D.J. (2012). Improving the sustainability of impacts of agricultural water management interventions in challenging contexts: the case study for Sri Lanka. Colombo: International Water Management Institute.

Karunanayake, M.M \& Abhayaratne, M.D.C. (2002). Redefining regional development in Sri Lanka: realities and challenges. CMU. Journal, 1(3), 303-319.

Lake, D. A., \& Rothchild, R. (2005). Territorial decentralization and civil war settlement. In F.G. Roeder \& D. Ruthchild (Eds). Sustainable peace: power and democracy after civil wars. (pp.109-132). New York: Cornel University press.

Linder, W. (2009). On the merits of decentralization in young democracies. Polibius: The Journal of Federalism, 40(1), 1-30.

Matthews, B. (1982). District development council in Sri Lanka. Asian Survey, 22(11), 117-1134.

Nadarajah, S. (1997). Evolution of administrative reforms. In Somasundaram, M. (Ed). The third wave: governance and public administration in Sri Lanka. (pp.239-262). Colombo: Vijita Yappa.

Oberst, R. (1986). Administrative conflict and decentralization: the case of Sri Lanka. Public Administration and Development, 6, 163174.

Perera, S. (2011). Reflections on issues of language in Sri Lanka: power, exclusion and inclusion. Groundviews [Online] Available: http://groundviews.org/2011/10/24/reflections-on-issues-of-language-in-sri-lanka-power-exclusion-and-inclusion/ (December 6, 2014).

Ranasinge, R.A.W. (2014). The role of government agent in local administration in Sri Lanka. International Journal of Education and Research, 2(2), 1-14.

Rondinelli, D. A., \& Cheema, G. S. (1983). Implementing decentralization policies. In G. S Cheema \& D. A Rondinelli (Eds). Decentralization and development: policy implementation in developing countries. (pp.1-18). New Delhi: Sage Publications.

Samaratunge, R \& Bennington, L. (2002). New public management: challenge for Sri Lanka. Asian Journal of Public Administration, 22(1), 87-109.

Schneider, A. (2003). Decentralization: conceptualization and measurement. Studies in Comparative International Development, 38(3), $32-56$.

Siegle J., \& O'Mahony. P. (2009). Assessing the merits of decentralization as a conflict mitigation strategy: Background paper prepared for the revision of the United States Agency for International Development (USAID) decentralization and democratic governance handbook. Washington, DC: USAID.

Sivakumar, N. (2013). Development via sub-national government in Sri Lanka: Challenges and opportunities. International Journal of Education and Research, 1(11), 1-14.

Tressie Leitan, G.R., (1979). Local government and decentralized administration in Sri Lanka. Colombo: Lake House Investments Ltd.

Turner, M. (2006). From commitment to consequences: comparative experiences of decentralization in the Philippines, Indonesia and Cambodia. Public Management Review, 8(2), 253-272.

Wijeweera, B.S. (1988). A colonial administrative system in transition: the experience of Sri Lanka. Colombo: Marga Publications (pvt.). 